\title{
SPA17 Gene
}

National Cancer Institute

\section{Source}

National Cancer Institute. SPA17 Gene. NCI Thesaurus. Code C142990.

This gene plays a role in binding to carbohydrates in the zona pellucida. 